\title{
A New Immunosuppressive Protein in Pig Spleen
}

\author{
Hongyan Fu1, Juan Feng2, Shaoguang Fan² \\ Department of Physiology and Pathophysiology, Peking University Health Science Center, Beijing, China \\ Email: fhy203964@sina.com
}

Received 30 May 2014; revised 30 June 2014; accepted 31 July 2014

Copyright (C) 2014 by authors and Scientific Research Publishing Inc.

This work is licensed under the Creative Commons Attribution International License (CC BY). http://creativecommons.org/licenses/by/4.0/

c) (i) Open Access

\section{Abstract}

Chronic stress has been the popular phenomenon in the modern society. But we have not yet resolved the problem effectively. A novel protein in pig spleen, which possesses immunosuppressive activity, has been purified in this study. Its molecular weight about $200 \mathrm{kDa}$ and three subunits composition were fractionated by SDS-PAGE. The protein inhibited mouse T-lymphocyte proliferation by the induced concanavalin $A$ (ConA) and regulatory volume decrease (RVD), which may be due to the decreased Kv1.3 expression and activity. In addition, we have raised successfully its polyclonal antibody, which could reverse the inhibited lymphocyte proliferation by the immunosuppressive protein. And the antibody could be used to coat plate for ELISA assay. Therefore, the antibody will have the potential to provide a basis for applying to clinical stress diseases in the future.

\section{Keywords}

Immunosuppressive Protein, Lymphocyte Proliferation, Pig, Kv1.3, RVD

\section{Introduction}

Complex diseases are chronic diseases where the interrelations between genetic predisposition and environmental factors play an essential role in the arising and the maintenance of the pathology. Upon psychological stress, the hypothalamic-pituitary-adrenal axis and the sympathetic nervous system are activated resulting in release of glucocorticoids, catecholamines and immune suppressive protein (ISP), where alterations of nervous, endocrine and immune systems are involved. Basic and clinical studies have demonstrated that chronic stress is associated with reduced immune responses. ISP is a key factor in the stress-immunity relationship. Chronic stress has been the popular phenomenon in the modern society, but we have not yet resolved the problem effectively. It can be hypothesized that antibody against the protein has the potential use for diagnosis and treatment for people 
troubled with various stresses.

Work from our laboratory has shown that there is a protein (ISP), which could inhibit the lymphocyte proliferation under the control of the central nervous system in mice and rats subjected to restraint stress. Previously the protein was obtained from the spleen and lymphocyte nodes of mice [1] [2]. But it is limited to use in clinical trials which are lacking quantity purified from small animals such as mice and rats. In the present study, a protein having the same activity has been isolated and purified from the spleens of pigs [3] [4]. Its immunosuppressive action mechanisms have been preliminarily studied here. More importantly, in this study the polyclonal antibody against the protein has been produced successfully [5] [6], which could block the suppressive activity of the protein. It will provide a basis for its applying to clinical stress disease in the future.

\section{Materials and Methods}

\subsection{Materials}

2C4 hybridization Neoplasia cells [7] were provided by the Neuroimmunne Laboratory of Beijing University, horse-radish peroxides coupled sheep antirat IgG and Biotin coupled sheep antimouse IgG were purchased from Sigma Chemical Company (St. Louis, Missouri, USA), ÄKTA FPLC chromatography apparatus was obtained from Pharmacia (Amersham Pharmacia Biotech company, Australian); Fresh pig spleens were obtained from the Beijing abattoir.

\subsection{Extract Protein}

Fresh pig spleens were processed by first being homogenized in $10 \mathrm{ml} 0.005 \mathrm{M} \mathrm{HCL} / \mathrm{g}$ tissue and centrifuged at $15,553 \times \mathrm{g}$ for $20 \mathrm{~min}$ at $4^{\circ} \mathrm{C}$. The supernatant solution was lyophilized and redissolved in pH 7.4, $0.01 \mathrm{M}$ phosphate buffered saline (PBS), It was then put into the Ultrafree-500 Filter Device Gradocal (Millipore Corporation, USA) with a membrane that retains proteins whose molecular weight is greater than $30 \mathrm{kDa}$. The solution was concentrated to one-tenth the original volume.

\subsection{Preparation of McAb}

After removal from liquid nitrogen the $2 \mathrm{C} 4$ cells line was quickly defrosted at $38^{\circ} \mathrm{C}$ for 1 - 2 min, then mixed with 5 - 8 ml RPMI 1640 medium containing 10\% fetal calf serum, 100,000 IU/L penicillin, and 100 mg/L streptomycin. The solution was centrifuged at $200 \times \mathrm{g}$ for $10 \mathrm{~min}$. The precipitate was harvested and suspended in RPMI 1640 medium, incubated at $37^{\circ} \mathrm{C}$ in an atmosphere of 5\% CO2. BALB/C mice were individually injected $0.5 \mathrm{ml}$ pristine intraperitoneally After 10 days each mouse was injected with $0.5 \mathrm{ml}$ RPMI-1640 containing $1 \times 106$ tumor cells. After one week the ascites was withdrawn. The suspension was centrifuged $200 \times \mathrm{g}$ at $4^{\circ} \mathrm{C}$ for $10 \mathrm{~min}$, then the supernatant was stored at $-20^{\circ} \mathrm{C}$. PH 7 saturated (NH4) $2 \mathrm{SO} 4$ solution equal volume was added to ascites supernatant solution drop-by-drop, mixture stored at room temperature for the night. Then precipitate was centrifuged at $4^{\circ} \mathrm{C}$ for $20 \mathrm{~min}$ at $15,553 \times \mathrm{g}$ The sediment was redissolved in $0.01 \mathrm{M} \mathrm{pH} 7.4 \mathrm{PBS}$, the volume of which was 1/5 that of the original ascites Solution was dialyzed against $0.01 \mathrm{M}$ pH $7.4 \mathrm{PBS}$ until there didn't appear BaSO4 sediments in dialyzed solution anymore and adjusted pH to 8.0. Then injected the processed ascites $2 \mathrm{ml}$ into Hitrap r protein A column (17-0717-01 Pharmacia) was purified, washed the column by $0.01 \mathrm{M} \mathrm{pH} \mathrm{8.0} \mathrm{PBS,} \mathrm{After} \mathrm{a} \mathrm{foreign} \mathrm{matter} \mathrm{peak} \mathrm{was} \mathrm{detected} \mathrm{by} \mathrm{UV} \mathrm{absorbance} \mathrm{at} 280 \mathrm{~nm}$ changed $0.1 \mathrm{M}$ $\mathrm{pH} 3.0$ acetate buffer solution to elute in order to get the McAb that was absorbed on the column, The elute which contained McAb was collected [8].

\subsection{McAb Coupled FPLC (Middle Pressure Liquid Chromatography of Pharmacia ÄKTA) Affinity Chromatography Column}

$10 \mathrm{ml}$ purified McAb was concentrated by Ultra filtration to $1 \mathrm{ml}$ and the protein concentration determined by the method of Bradford. First, the column was then washed to remove the isopropanol with $6 \mathrm{ml}$ of cold $1 \mathrm{mM}$ HCL at a flow-rate of $1 \mathrm{ml} / \mathrm{min}$, and $1 \mathrm{ml}$ of ligand solution containing $15 \mathrm{mg}$ McAb was injected to couple the $\mathrm{McAb}$ to the beads. and stored at $4^{\circ} \mathrm{C}$ for 4 hours, second, Added $6 \mathrm{ml}$ buffer $\mathrm{B}(0.1 \mathrm{M}$ Acetate including $0.5 \mathrm{M}$ pH4 NaCl), then added $6 \mathrm{ml}$ buffer A (0.5 M Ethanol amine, $0.5 \mathrm{M} \mathrm{NaCl}(\mathrm{pH} 8.3)$ again and keep it in the column for 15 - 30 min. Third, the column was washed in turn by 6 ml Buffer B, 6 ml Buffer A and 6 ml Buffer B, 
at last added $2 \mathrm{ml}$ neutral buffer PBS to regulate the $\mathrm{pH}$, added $4 \mathrm{ml} 0.05 \mathrm{M} \mathrm{NaH2PO} 4$ solution (including $0.1 \%$ sodium azide, stored in $20 \%$ alcohol at last.)

\subsection{Purify Protein by FPLC}

The coupled McAb column was washed with PBS (0.05 M pH 8.00) at a speed of $0.5 \mathrm{ml} / \mathrm{min}$ until the curve kept steadily, injected $2 \mathrm{ml}$ sample and kept for one hour or so, washed by buffer PBS (0.05 M pH 8.00) again. At the same time, there appeared flow through peak. When the curve returned to basal absorbance, Acid citric $(0.1 \mathrm{M} \mathrm{pH}$ 3.0) was used to wash down the protein absorbed on the column and collect to determinations content of the protein and activity of it.

\subsection{Lymphocyte Proliferation Experiment}

Lymphocyte of BALB/C mice were suspended in RPMI1640 medium with 10\% heat inactivated calf serum; L-glutamine $(20 \mathrm{mM})$, antibiotics (100 u/ml penicillin, $100 \mathrm{ug} / \mathrm{ml}$ streptomycin) and ConA were placed in well of a 96-well flat-bottom plate. The final concentration of the lymphocytes was $2 \times 106 \mathrm{cells} / \mathrm{ml}$, and ConA was 2 $\mathrm{ug} / \mathrm{ml}$, respectively. All cultures determinations were performed in triplicate, and each group was filled which different density sample. The cultures were incubated at $37^{\circ} \mathrm{C}$ in a humidified atmosphere of $5 \% \mathrm{CO}^{2}$ [3H]-TdR (thymidine) was added to each culture after 42 hours incubation. Radioactivity was assayed in a liquid scintillation counter and presented as counts per minute (cpm).

\subsection{Polyclonal Antibody Preparation}

Polyclonal antibodies were raised from rabbits by subcutaneous injections of purified $200 \mathrm{KD}$ (50 ug/rat) protein with activity, emulsified with complete Freund's adjuvant as first immunization, emulsified with incomplete Freund's adjuvant as reinforcement immunization After succeed obtain antisera, it's affinity and specificity to our aim protein were tested by ELISA and reverse protein lymphocyte suppressive action.

\subsection{ELISA Test}

The purified protein from FPLC was dissolved $5 \mathrm{ug} / \mathrm{ml}$ to $50 \mathrm{mM} \mathrm{pH} 9.5$ carbonate buffer, $100 \mathrm{ul} /$ well coat enzyme marked plates. Titrate 2C4-McAb 100 ul/well; second antibody was sheep-anti mice IgG (1:1000) 100 ul/well, added substrate OPD $0.04 \mathrm{mg} /$ well display color. Opticaldensity (O.D. Value) was measured at wavelength $492 \mathrm{~nm}$ in enzyme labeling instrument.

\subsection{SDS-PAGE}

The purified protein protein $15 \mathrm{ul}$ add into $2 \mathrm{ml}$ sample buffer boiling $5 \mathrm{~min}$, added sample and molecular weight markers between 212,000 and 53,000 Da were used to enable estimation of the size and purified degree of the separated proteins. Electrophoresis was carried out at $4^{\circ} \mathrm{C}$ to minimize gel heating and distortion and each gel was run at an initial voltage of $90 \mathrm{~V}$ and a constant current of $20 \mathrm{~mA}$ for approximately $1 \mathrm{hr}$ until Bromophenol blue ran to the end of the gel. The gel was removed and put into staining liquid for 2 hours, then into bleaching liquid. After bleaching, a picture was taken with a gel Imaging System.

\subsection{A Study of ISP on the Effect of $K^{+}$Channel on Regulatory Volume Decrease (RVD) in Jurkat Cells}

It is evident that in $\mathrm{T}$ cells the opening of $\mathrm{K}^{+}$channel in the cell membrane carries out RVD. Therefore, According to the literatures, RVD can be used for an index to show the opening of $\mathrm{K}^{+}$channel. RVD is found in the cell when it is exposed to hypo osmotic solutions. When exposed to hypo osmotic solutions, T cells swell rapidly, and then shrink over several minutes back to approximately their normal size. This regulatory volume decrease-RVD. First, cells were put in isotonic solution for 2 minutes, and then were put in hypo osmotic solutions. Take the image every 15-second in the process until 900 second. The acquired cell image signal was transferred to digital signal by CCD from microscope, and is transported to monitor, and be shown on the screen. An imaging analysis system (RS-Image MediaView Image System, Windows XP, Microsoft Excel) was used for the real time measurement of cell volume under the conditions of hypo tonic stress in Jurkat cells. 


\subsection{Kv1.3 Expression}

After ISPS incubated Jurkat cell $15 \mathrm{hr}$, cell viability was determined to be $>96 \%$ by trypan blue dye exclusion, and cell pellets were obtained by centrifugation at $400 \times \mathrm{g}$ for $10 \mathrm{~min}$. Kv1.3 channel expression difference between ISPS incubated and control (without incubation with ISPS) of T lymphocyte. RT-PCR (reverse transcriptase polymerase chain reaction) techniques were employed as described (). Extracted cellular RNA samples were reverse transcribed into cDNA and amplified using Kv1.3 specific primers (up primer: 5,-CGC TGG CCA TCC TAA GAG A-3'; Downprimer 5,-GCA CAG AAT TGG CAA CCG TA-3' amplified segment: 680 bp retrofire temperature: $57.2^{\circ} \mathrm{C}$ ) in the following PCR program: $94^{\circ} \mathrm{C} 45 \mathrm{sec} ; 57.2^{\circ} \mathrm{C} 1 \mathrm{~min} ; 720^{\circ} \mathrm{C} 1 \mathrm{~min}$ for 30 cycles. The amplified cDNA of the Kv1.3 transcript was analyzed by 1.5\% agrose gel electrphoresis and the bands were visualized by ethidium bromide staining.

\section{Statistical Analysis}

All data are reported as means \pm S.E. unless mentioned. Statistical analysis of different treatments involved the Student's unpaired t-test for two-way comparison. Analysis of variance (ANOVA) was used for differences between means ( $\mathrm{F}$ test), with significant difference $\mathrm{p}<0.05$.

\section{Results}

\subsection{Fundamental Feature of the New Explored Protein in Pig Spleen}

Using Hitrap Protein A (Pharmacia) $1 \mathrm{ml}, 0.01 \mathrm{M} \mathrm{pH} 8.0$ PBS buffer balance column for $30 \mathrm{~min}, 1 \mathrm{ml}$ ascites fluid was added to the column. PBS eluted a multiprotein peak with flow rate $0.5 \mathrm{ml} / \mathrm{min}$, after curve stable return to base line, using $0.1 \mathrm{M} \mathrm{pH} 3.0$ citric acid buffer to wash the column in order to get the McAb that was absorbed on the column. Then the column was balanced by $0.01 \mathrm{M} \mathrm{pH} 8.0$ PBS once more. Repeat this process. $\mathrm{McAb}$ was collected together and centrifuged to concentration in ultra filter tube $\left(4^{\circ} \mathrm{C} 3000 \mathrm{\times g}\right)$, tested the content of the protein (see Figure 1).

\subsection{FPLC Purify Protein}

Flow rate was $0.5 \mathrm{ml} / \mathrm{min}$, pH 3.0 citric acid as elute liquid, PBS $0.05 \mathrm{M} \mathrm{pH} 8.0$ as balance buffer. Using 15 $\mathrm{mg} / \mathrm{ml}$ McAb coupling Hitrap NHS-activated (17-0717-01 Pharmacia) affinity column. Repeat above process, collecting all eluted ISP (immune suppressive protein of pig spleen) Figure 2.

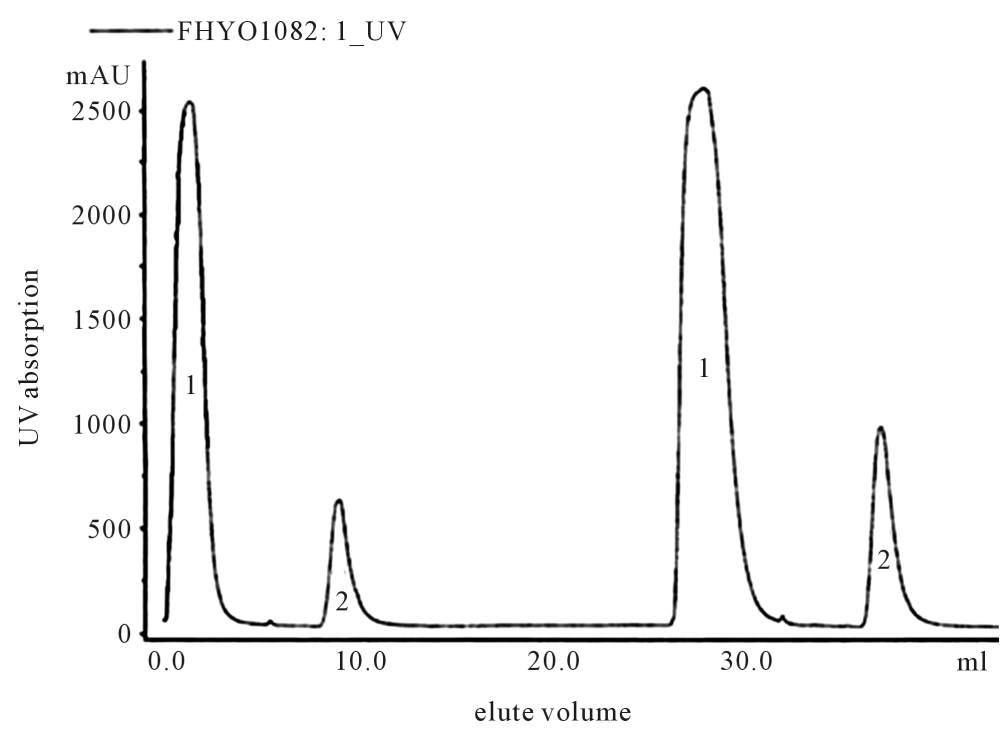

Figure 1. Hitrap protein A purified 2C4-McAb. Purification of 2C4-McAb with Hitrap protein A column. Peak 1, multi-protein eluted with PBS (0.05 $\mathrm{mol} / \mathrm{L}, \mathrm{pH}$ 8.0), Peak 2 2C4-McAb eluted with citric acid (0.1 mol/L, $\mathrm{pH} 3.0)$. 


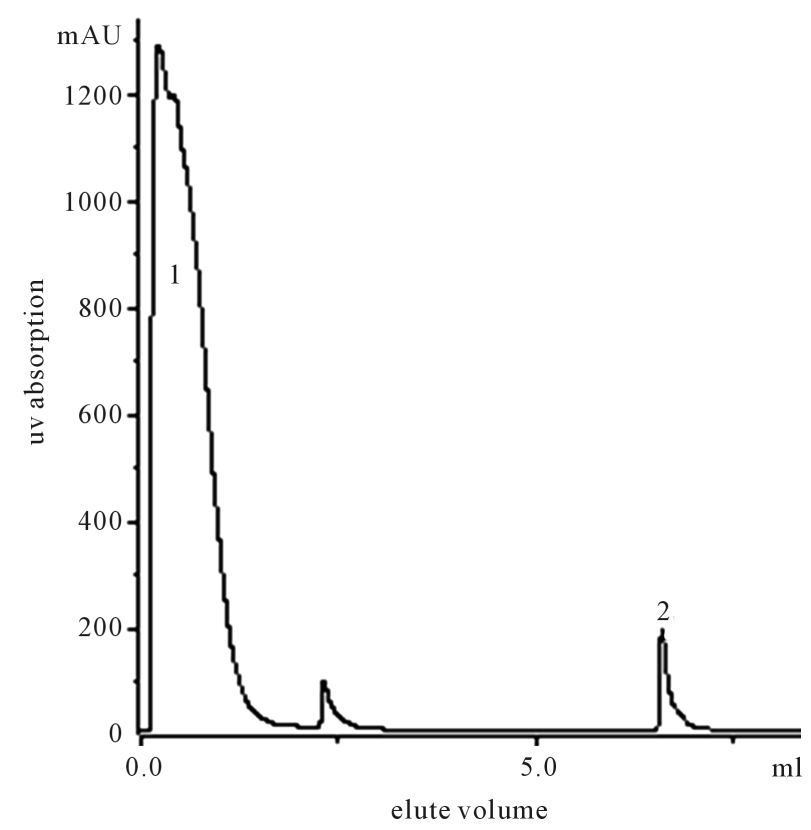

Figure 2. Purification of pig spleen extract by FPLC. Peak 1 was $0.05 \mathrm{M}$, pH 8.0, PBS eluted multiprotein, Peak 2 was 0.1 $\mathrm{M}$, pH 3.0 citric acid eluted sample protein.

\subsection{SDS-PAGE Estimated the Purified Protein Molecular Weight}

The molecular weight of the protein under investigation was determined by comparing its electrophoresis mobility with that of the known molecular weight in the kit proteins (Marker was High Molecular weight Calibration Kit, Pharmacia Biotech). Strip tested that ISP purification degree was very good; we assessed its molecular weight in position of $200 \mathrm{Kda}$ or so. And after opened its S-S linkage with 2-mercaptoethonal we found it was composed of three bands in Figure 3(b). Band 1, 2, 3 were in the position of $70 \mathrm{Kda} ; 60 \mathrm{Kda} ; 0$ Kda or so respectively. So we assessed it was composed of three subunits (See Figure 3).

\subsection{The Purified Protein Function and Activity Test}

\subsubsection{Lymphocyte Proliferation Test Protein Activity}

Protein and as control multiprotein from the above FPLC were added to the cell culture medium at final concentrations of $2 \mathrm{ug}, 1 \mathrm{ug}, 0.5 \mathrm{ug}$, and $0.25 \mathrm{ug}$. Each dose point is the average of triplicate cultures, mean \pm SEM. The normal mouse lymphocyte proliferation induced by ConA $(2 \mathrm{ug} / \mathrm{ml})$ in 2 ug group $(29795.6 \pm 799.4$, $44165.33 \pm 648.76$; $\mathrm{P}<0.001$, ANOVA, $\mathrm{n}=7$ ). This result indicates that the purified pig spleen protein significantly suppressed normal lymphocyte proliferation (Figure 4).

\subsubsection{Selective Suppression Effect of the Protein on Cell Proliferation}

Six cell lines including U937 (macrophage), Mel (erythrocyte), 373 (fibroblast), Jurket cell (T cell), P810 (mast cell) and Hepatocarcinoma were used for testing the effect of the protein on cell proliferation [9]. Methods similar to above. Black columns represent the cell proliferation without adding the purified protein ( $2 \mu \mathrm{g} / \mathrm{well})$. Cell proliferation of the cell line originating from immune cell such as U937, Jurket cell and P810 were suppressed significantly. It suggested that the suppressive effect of the protein on cell proliferation was selective. This suggests that the pig ISPS homologue has selective proliferation suppression activity on different cell lines. The nature of the selectivity also remains obscure (Figure 5).

\subsubsection{Polyclonal Antibody Reverse Protein Activities}

Polyclonal antibody $0.25 \mathrm{ug} / \mathrm{ul}$ with protein $2 \mathrm{ug} / \mathrm{ul}$ was incubated in each well 2 hour at $37^{\circ} \mathrm{C}$. Then added ConA-activated lymphocyte suspension. As a measure of lymphocyte proliferation, [3H] thymidine $(1 \mu \mathrm{Ci} / \mathrm{well})$ 


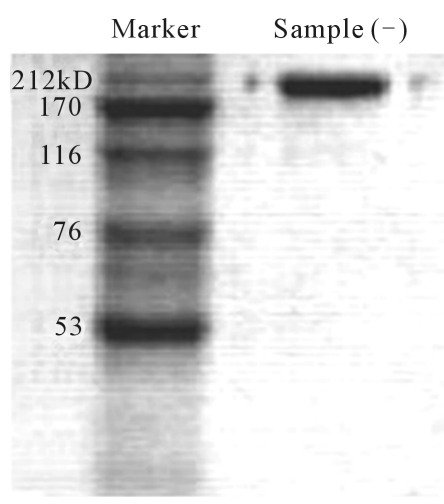

(a)

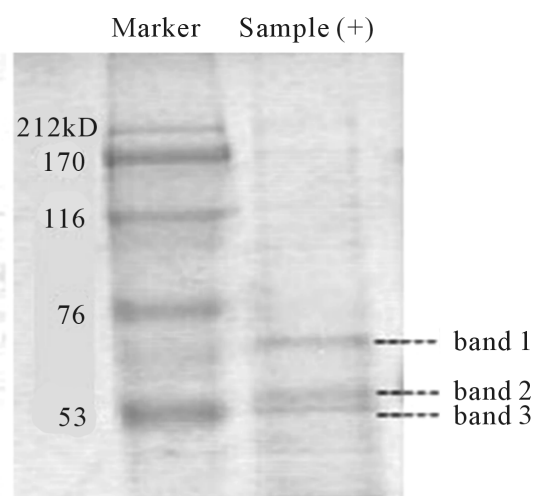

(b)

Figure 3. SDS-PAGE of purified sample from pig spleen. Sample (-) and sample $(+)$ represent the treatment without and with 2-mercaptoethanol respectively in (a) and (b). Acrylamide concentration was 7\% for (a) and $10 \%$ for (b).

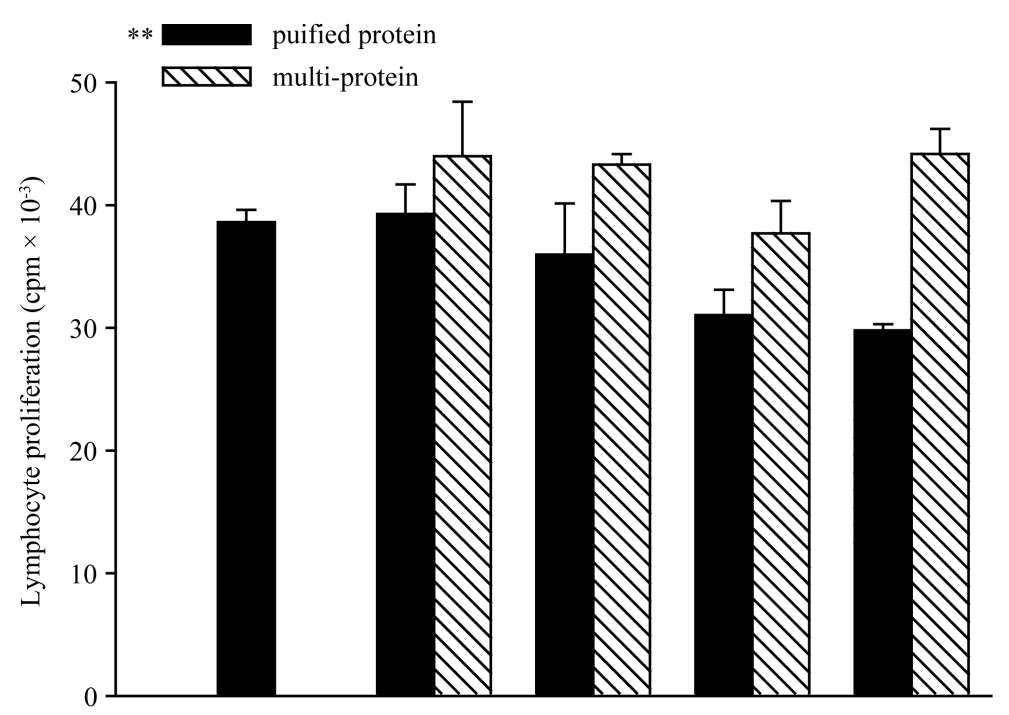

Figure 4. Con A+, lymphocyte proliferation induced by C on A (2 $\mu \mathrm{g} / \mathrm{ml})$; Multi-protein, culture medium containing Con A ( $2 \mu \mathrm{g} / \mathrm{ml})$ and multi-protein; Purified protein, culture medium containing Con A $(2 \mu \mathrm{g} / \mathrm{ml})$ and the purified protein. **, $\mathrm{P}<0.01$ compared with multi-protein (ANOVA, $\mathrm{n}=3$ ).

uptake during the last 6 hours of a 2-day incubation was determined. Observe polyclonal antibody against ISP affected on protein suppressive activities (Figure 6).

\subsubsection{ELISA Tested the Protein Characteristic}

The purified protein and multiprotein respectively $5 \mathrm{ug} / \mathrm{ml}$ coat enzyme marked plates. Titrate 2C4 McAb 100 ul/well; second antibody was sheep-anti mice IgG (1:1000) $100 \mathrm{ul} /$ well, added substrate OPD $0.04 \mathrm{mg} /$ well display color. Optical density (O.D. Value) was measured at wavelength $492 \mathrm{~nm}$ in enzyme labeling instrument. The ELISA was tested to compare the two parts. According to the result, the purified protein that could combine with McAb, while multiprotein did not have such substance (Figure 7).

\subsection{Study of Possible Mechanisms}

\subsubsection{ISPS Synergetic Action with K Channel Blockades in Lymphocyte}

$0.1 \mathrm{mM}$ Quinine is K channel blockades dependent calcium, possess inhibits lymphocyte proliferation effect. 


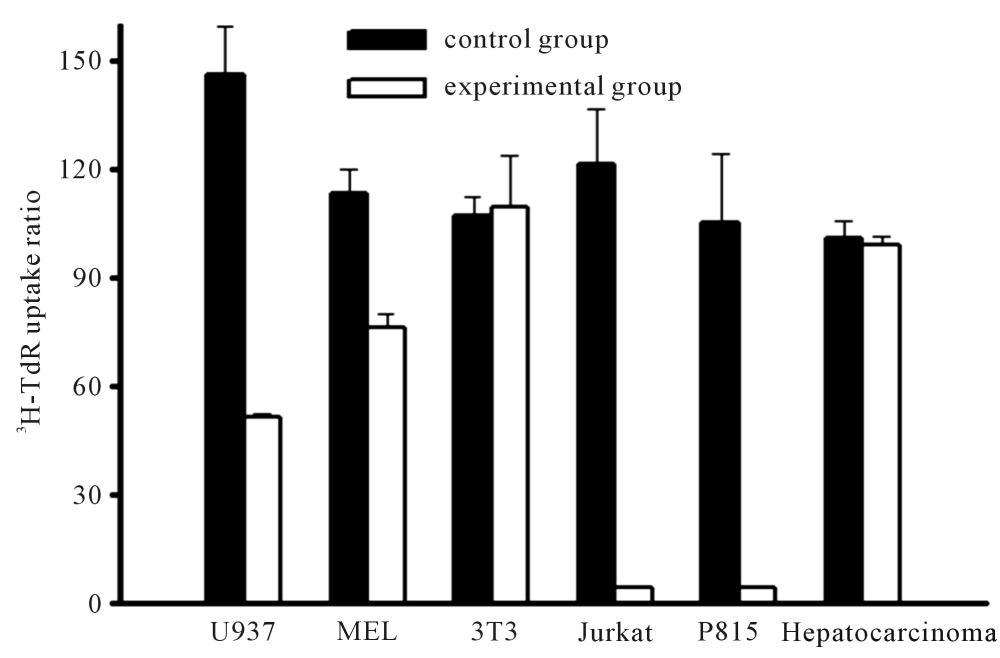

Figure 5. Selective effect of the extract on cell proliferation of various cell lines. Six cell lines including U 937, Mel, 373, Jurket cell, P 810, and Hepatocarcinoma were used for testing the effect of the protein on cell proliferation. The first 5 cell lines are macrophage, erythrocyte, fibroblast, T cell, and mast cell origin, respectively. Mean $\pm \mathrm{SD}$. bP $<0.05$ and $\mathrm{cP}<0.01$ vs control (t-test, $n=3$ ).

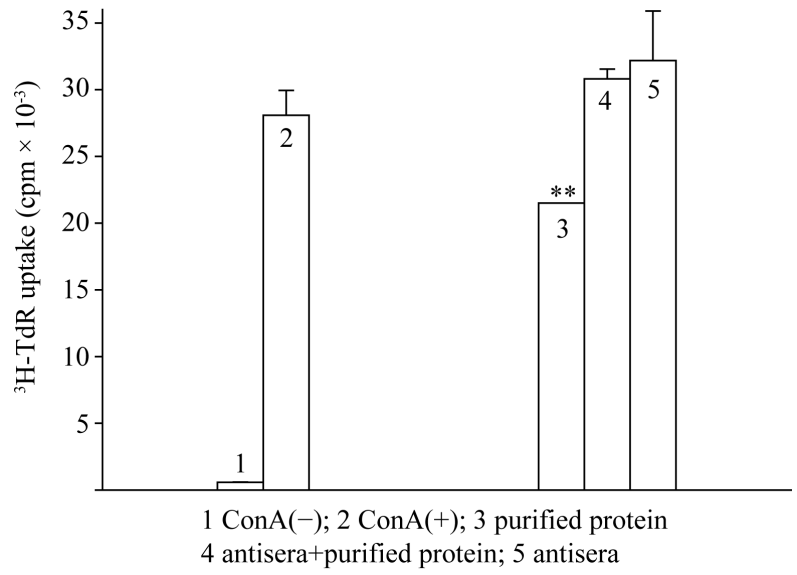

Figure 6. Antagonistic effect of the antiserum on the inhibition of lymphocyteproliferation induced by the purified protein from pig spleen.

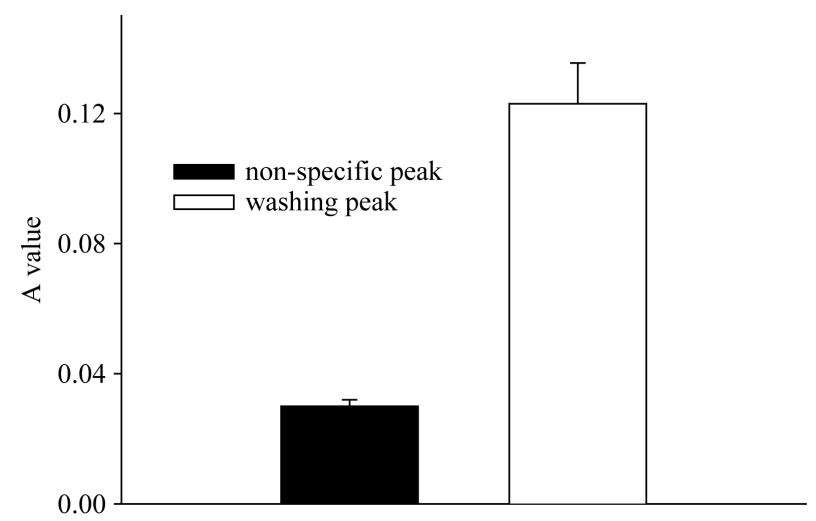

Figure 7. Specificity identification to ISPS by ELISA T test, $\mathrm{n}=8$. black column, $\mathrm{p}<0.05$ compared with white column. 
ISP has synergistic action with quinine in lymphocyte proliferation. Method same was above 3.4. The results showed that ConA(+) control group CPM was 14,738 \pm 1132.63 ; alone applied ISPS and quinine respectively was $9384 \pm 350$ and $8423.5 \pm 379.5$; union applied both lymphocyte proliferation was $7043.5 \pm 403.5$ (Figure 8).

\subsubsection{RVD Results}

RVD in $5 \times 10^{6} \mathrm{ml}$ Jurkat cell was found to be marked inhibited under the conditions of $2 \mathrm{ul} / \mathrm{ml}$ ISP (eluted fraction from affinity chromatography column) incubation $12 \mathrm{hrs}$, But the same dose multiprotein (component of unable combine to affinity column ) and negative control (added nothing), had not affect to RVD in Jurkat cell. It implied that one of possible reasons for the inhibition on immune function induced by ISP may be the suppression on opening of $\mathrm{K}^{+}$channel (Figure 9).

\subsubsection{Kv1.3 Channel Expression of Lymphocyte}

Kv1.3 channel expression difference between ISPS incubated 12 hrs and control (without incubation with ISPS) of T-lymphocyte as follow figure. Under the condition of ISPS incubated. It showed Kv1.3 of lymphocyte expression decrease (Figure 10).

\section{Discussion}

Both physiological function and pathological processes relate to the function of neuroendocrine and immune systems and the interaction of the two systems. There are many different components involved in hormones, cytokines, factors induced by stress such as ISP, which regulate the interaction mechanisms [10]. The neuroimmune system has a very significant influence on the beginning, development and prognosis of many illnesses. So many scientists have taken part in research upon its immunoregulation mechanisms and tried to develop related clinical intervention targets. Our previous work has evaluated the influence of the obtained purified protein

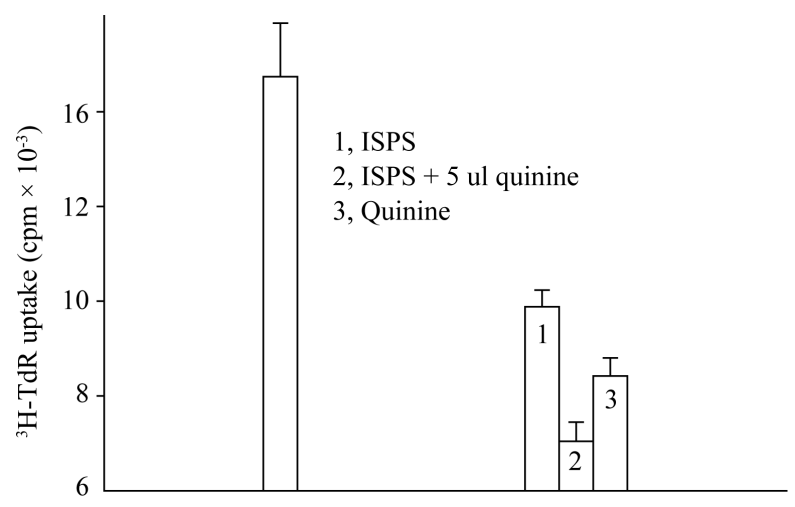

Figure 8. Synergistic action of ISPS and quinine.

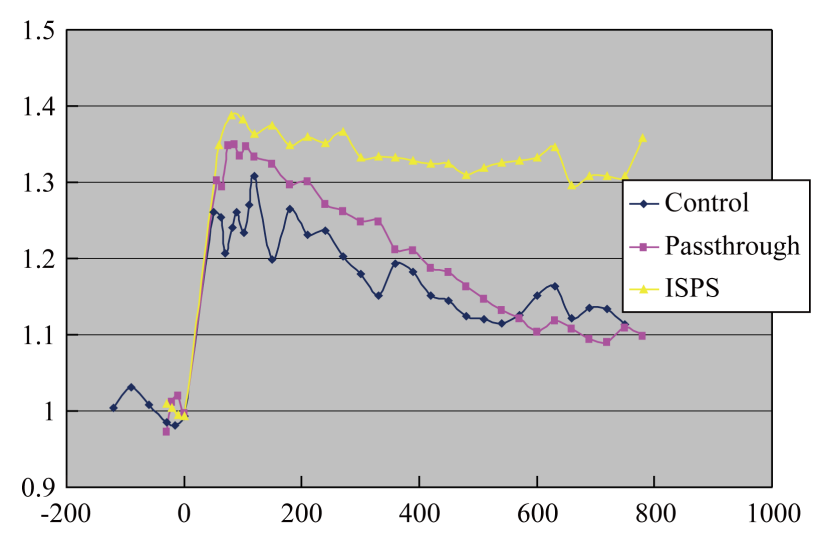

Figure 9. Effect of ISPS on RVD. 


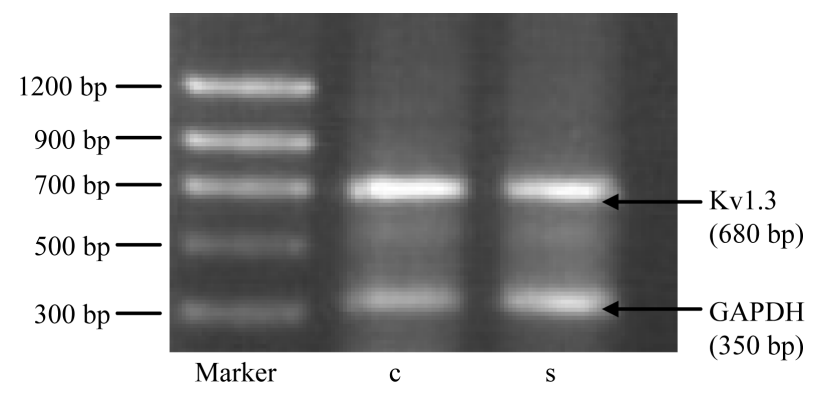

Figure 10. ISPS effect on Kv1.3 expression of lymphocyte. GADPH (control); S strip (Kv1.3 gene expression of lymphocyte incubated ISPS), C (Kv1.3 gene expression of lymphocyte without incubated ISPS).

(ISP) produced under the restraint stress on T-Lymphocyte proliferation and its characteristics [11] [12]. It can be expected to neutralize the suppressive protein to ameliorate stress-induced diseases. But the quantity purified from mice or rats is too low to develop antibody for further use in clinical trials [13].

Here, we purified a protein from pig spleen by using monoclonal antibody raised from mice [14]. The protein could inhibit the normal T-lymphocyte proliferation, which was similar to the suppressive protein produced under the restraint stress in mice. Its molecular weight $(200 \mathrm{kDa})$ and three subunits make it unlikely to be one of the well-known hormones, interleukins, interferon etc. It is possible that this protein is potentially a newly founded protein [15] [16].

There is increasing evidence to show that $\mathrm{K}^{+}$not only plays an important role in the formation of the cell membrane potential in lymphocytes but also in the regulation of the function of lymphocytes. RVD is an index for potassium channel function. Our data showed that purified ISP (eluted fraction from affinity chromatography) had marked inhibition on RVD of Jurkat T cell, and the unrelated protein (component of unable combine to affinity column) had no effect. It implied the involvement of potassium channels in the suppressive effect on immune function induced by ISP. It also was confirmed by downregulated expression of Kv1.3 gene in lymphocyte. But mechanism should be further studied.

More importantly, we raised successfully the polyclonal antibody against the suppressive protein, which could neutralize the effect of inhibited T-lymphocyte proliferation produced by restraint stress. It makes it possible for diagnosis and treatment for people troubling with various stresses in the future.

Taken together, our study found a new suppressive protein in pig spleens, which inhibited the T-lymphocyte proliferation, maybe at least in part, due to the downregulated potassium channel activity. The polyclonal antibody may be useful for further clinical trials although it needs more investigations.

\section{Acknowledgements}

This work was supported by a grant (81000115) from National Natural Foundation of China and Funding Project of Competence Development Program for Beijing VET Teachers.

\section{References}

[1] Zha, H.B., Ding, G.F. and Fan, S.G. (1992) Serum Factors Induced by Restraint Stress in Mice and Rats Suppress Lymphocyte Proliferation. Brain, Behavior, and Immunity, 6, 18-31. http://dx.doi.org/10.1016/0889-1591(92)90056-T

[2] Shao, L., Gao, S., Zhang, Q. and Ding, G.F. (1995) A Suppressive Factor Generated in Lymph Tissue on Lymphocyte Proliferation Induced by Restraint Stress. Chinese Science Bulletin, 40, 164-166.

[3] Fan, S.G., Gao, S., Shao, L., Mei, L. and Ding, G.F. (1995) A Suppressive Factor in Lymph Node and Spleen Induced by Restraint Stress Suppresses Lymphocyte Proliferation. Neuroimmunomodulation, 2, 274-281. http://dx.doi.org/10.1159/000097206

[4] Fan, S.G. and Zha, H.B. (1989) Effects of Restraint Stress on the Generation of Suppressive Factors in Mouse Serum. Chinese Science Bulletin, 20, 1584-1587.

[5] Zha, H.B., Xu, H., Zhe, Q.Z., Cheng, W. and Fan, S.G. (1991) A Study of Serum Suppressive Factors on Lymphocyte Proliferation under Restraint Stress in Rats. The Journal of Physiology, 43, 31-37. 
[6] Keller, S.E., Weiss, J.M., Schleifer, S.T., Miller, N.E. and Stein, M. (1981) Suppression of Immunity by Stress: Effect of Graded Series of Stresses on Lymphocyte Stimulation in the Rat. Science, 213, 1397-1400. http://dx.doi.org/10.1126/science.6973822

[7] Kohler, G. and Milstein, C. (1975) Continuous Culture of Fused Cells Secreting Antibody of Predefined Specificity. Nature, 256, 495-498. http://dx.doi.org/10.1038/256495a0

[8] Harlow, E. and Lane, D. (1975) Using Antibodies: Laboratory Manual. CSHL Press, New York, 313-346.

[9] Wolf, J.H.N., Wu, A.V.O., Connor, N.E., Saporoschetz, I. and Manick, J.A. (1982) Immunosuppressive Serum. An Impaired Lymphocyte Blastogenesis in Burns Patients. Archives of Surgery, 117, 1266-127. http://dx.doi.org/10.1001/archsurg.1982.01380340002002

[10] McLaughlin, G.A., Wu, A.V., Saporoschetz, I., Ninberg, R.B. and Mannick, J.A. (1979) Correlation between Anergy and a Circulating Immunosuppressive Factor Following Major Surgical Trauma. Annals of Surgery, 190, 297-304. http://dx.doi.org/10.1097/00000658-197909000-00004

[11] Ding, G.F., Deng, H.Y., Deng, Y.L., Pang, J. and Fan, S.G. (1984) The Effect of 5, 6-Dihydroxytryptryptamine on Lymphocyte Transformation Reaction of spleen Cells in Rats. Chinese Science Bulletin, 29, 1086-1090.

[12] Gao, S., Mei, L., Zhang, G.F. and Fan, S.G. (1984) An Inhibitory Effect of Restraint Stress on the Development of Diabetes Induced by Alloxan. Chinese Journal of Neuroimmunology and Neurology, 3, 95-98.

[13] Fan, S.G., Shao, L. and Ding, G.F. (1996) A Suppressive Protein Generated in Peripheral Lymph Tissue Induced by Restraint Stress. Advances in Neuroimmunology, 6, 278-288. http://dx.doi.org/10.1016/S0960-5428(96)00023-X

[14] Weber, K. and Osborn, M.J. (1969) The Reliability of Molecular Weight Determination by Dodecyl Sulphate Polyacrylamide Gel Electrophoresis. The Journal of Biological Chemistry, 244, 4406.

[15] Walker, J.M. (1996) The Bradford for Protein Quantitation. In: Walker, J.M., Ed., The Protein Protocols Handbook, 15-20.

[16] Alain, T. and Eric, V. (2001) Agrin—A Bridge between the Nervous and Immune Systems. Science, 292, 1667-1669. http://dx.doi.org/10.1126/science.1061542 
Scientific Research Publishing (SCIRP) is one of the largest Open Access journal publishers. It is currently publishing more than 200 open access, online, peer-reviewed journals covering a wide range of academic disciplines. SCIRP serves the worldwide academic communities and contributes to the progress and application of science with its publication.

Other selected journals from SCIRP are listed as below. Submit your manuscript to us via either submit@scirp.org or Online Submission Portal.
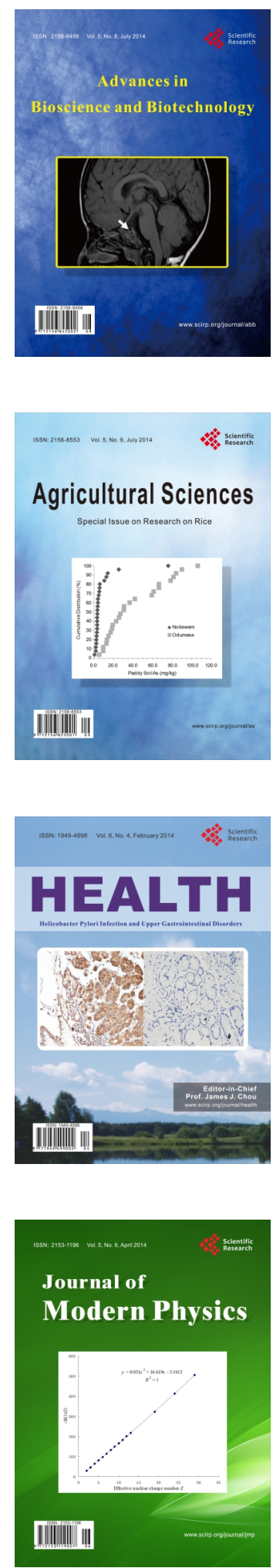
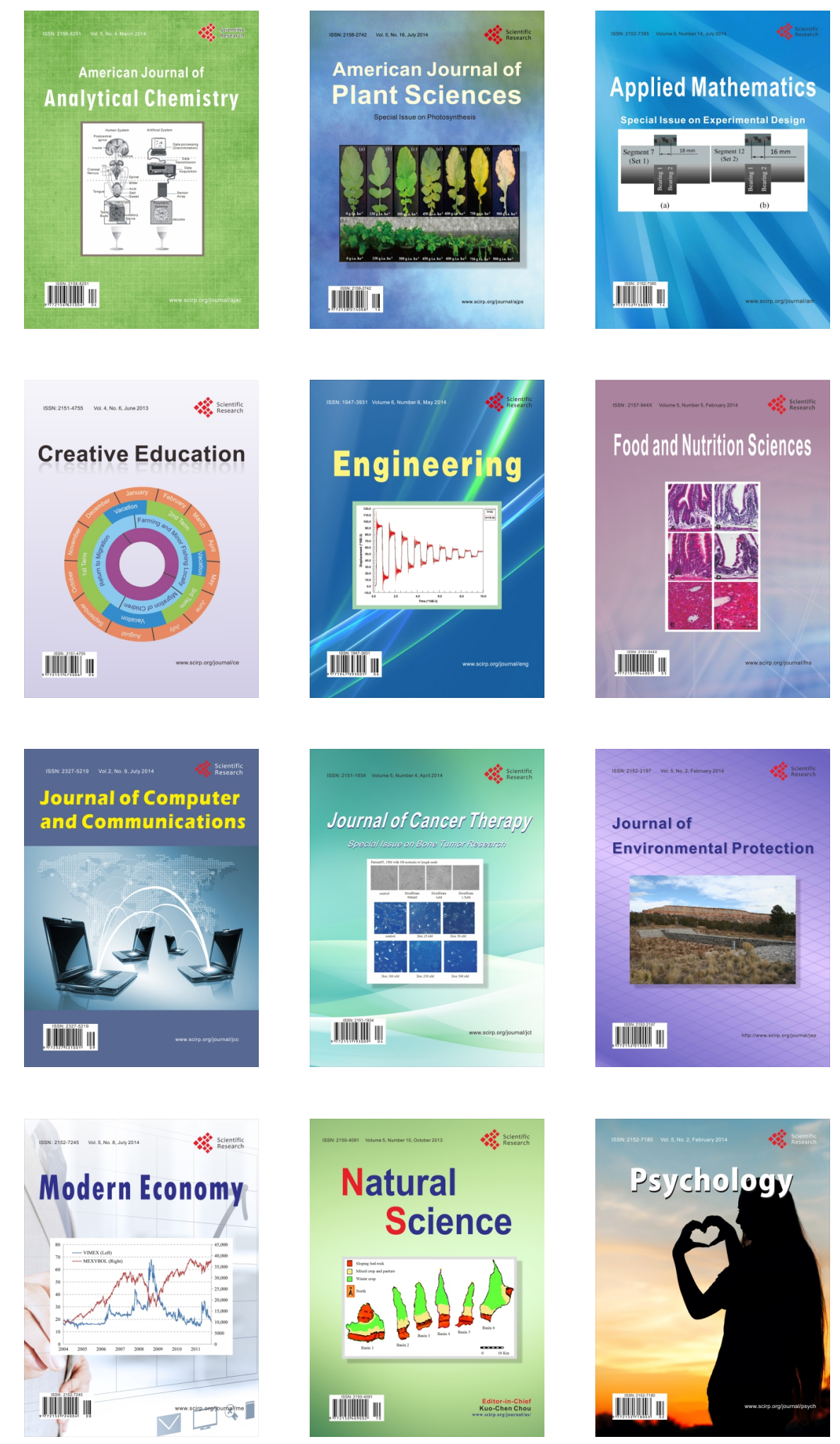